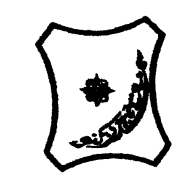

Bayero Journal of Pure and Applied Sciences, 11(1): 265 - 272

ISSN 2006 - 6996

\title{
INFLUENCE OF NEUTRON IRRADIATION AND PHOSPHORUS ON THE PERFORMANCE OF GROUNDNUT [Arachis hypogaea (L.)] GENOTYPES GROWN ON A P-DEFICIENT ALFISOLS AT SAMARU, NIGERIA
}

\author{
Gabasawa*1 $^{* 1}$ A.I. Ayami ${ }^{1}$ M.M. and Muhammad ${ }^{2}$ A.M. \\ ${ }^{1}$ Department of Soil Science, Faculty of Agriculture/Institute for Agricultural Research, Ahmadu \\ Bello University, PMB 1044, Samaru - Zaria, Nigeria, ${ }^{2}$ Centre for Energy Research and Training, \\ Ahmadu Bello University, PMB 1014, Samaru - Zaria, Nigeria \\ *Corresponding Author: +234 (0) 8065409 850, algabasawiyyu@yahoo.com
}

\section{ABSTRACT}

There is a dearth of information on the effective irradiation dose for inducing variability in groundnut genotypes. A screen house experiment was conducted at the Department of Soil Science, Ahmadu Bello University, Zaria (ABU). It was to investigate the effect of induced genetic variability (by neutron irradiation) and four phosphorus rates $(0,20,40$ and $60 \mathrm{~kg}$ $\mathrm{P}_{2} \mathrm{O}_{5} \mathrm{ha}^{-1}$ ) on the performance of some groundnut [(Arachis hypogaea (L.)] genotypes grown on a P-deficient Alfisols at Samaru, Zaria. A fraction of each of the two genotypes (SAMNUT 24 and SAMNUT 26) was irradiated, in a 5-Curie Americium-Beryllium (Am-Be) isotope neutron source, having a thermal neutron flux of $2.7387 \times 10^{4} \mathrm{n} \mathrm{cm}^{-2} \mathrm{sec}^{-1}$ for six days, at the Centre for Energy Research and Training, $A B U$. The irradiated $\left(G_{1 A}\right.$ and $\left.G_{2 A}\right)$ and nonradiated $\left(G_{1 B}\right.$ and $\left.G_{2 B}\right)$ seeds; and the $P$ rates were laid out in a randomised complete block design (RCBD), in a screen house, and replicated thrice. Data collected during the study included; plant height, numbers of branches, flowers, nodules, leaves and chlorophyll content $(C C)$. Both $G_{1 A}$ and $G_{2 A}$ significantly $(P<0.0001)$ produced the highest $C C$, highest numbers of branches, leaves, flowers, nodules and effective nodules; and the tallest plants. Treatment with $60 \mathrm{~kg} \mathrm{P}_{2} \mathrm{O}_{5} \mathrm{ha}^{-1}$ significantly $(P<0.0001)$ increased the number of leaves, flowers, branches and plant height. The irradiated genotypes were generally observed to significantly perform better than their non-radiated counterparts under the application of both $60 \mathrm{~kg} \mathrm{P} \mathrm{P}_{2} \mathrm{O}_{5} \mathrm{ha}^{-1}$ and $20 \mathrm{~kg} \mathrm{P}_{2} \mathrm{O}_{5} \mathrm{ha}^{-1}$. Thus, application of $20 \mathrm{~kg} \mathrm{P}_{2} \mathrm{O}_{5} \mathrm{ha}^{-1}$ is recommended for optimum plant height, flowers and CC in groundnut production; while $60 \mathrm{~kg} \mathrm{P}_{2} \mathrm{O}_{5} \mathrm{ha}^{-1}$ is recommended for optimum numbers of branches and leaves, especially when the irradiated SAMNUT 24 and SAMNUT 26 are to be used for production of both seeds and biomass.

Keywords: Alfisols, Chlorophyll content, Neutron irradiation, SAMNUT

\section{INTRODUCTION}

Groundnut (Arachis hypogaea L.), a selfpollinating crop, belongs to the family Fabaceae, sub-family Papilionidae, tribe Aeschomeneae, sub-tribe Stylosanthinae, genus Arachis and species hypogaea (Isleib et al., 1994). It is an annual herb with an indeterminate growth habit and ranks $13^{\text {th }}$ among the world food crops, $4^{\text {th }}$ most important source of edible oil and $3^{\text {rd }}$ most important source of vegetable protein FAOSTAT (2011). Nigeria is the largest producer in Africa, producing $30 \%$ of the Continent's total production, followed by Senegal and Sudan, each with about $8 \%$; and Ghana and Chad, with about $5 \%$ each (Gwata et al., 2003). Groundnut seeds are mainly comprised of protein, fat and carbohydrate. This makes it sensitive to radiation induced stress. High gamma rays $(0.7$ - 2.3 KiloGray) have suppressive effects on germination and growth parameters of groundnut (Aparna et al., 2012); however, low doses have been reported to be beneficial (Tshilenge-Lukanda et al., 2013). Gamma rays produce radicals that can damage or differentially affect plant morphology, anatomy, biochemistry and physiology. Lower exposures to gamma rays were sometimes stimulatory and several studies have reported improvement in agronomic characteristics in radiated groundnuts (Tshilenge-Lukanda et al., 2013). Radiation induced mutation played a significant role in the improvement of groundnut genotypes with a large number of pods and high yield have been developed in many countries (Ramani and Jadon, 1991; Micke, 1997).

Phosphorus (P) is one of the most essential elements for plant growth and therefore its deficiency is a factor that limits crop production in tropical and sub-tropical soils (Fairhust et al., 1999). 
It is considered the second most limiting element for crops, after nitrogen ( $N$ ) (Arcand and Schneider, 2006). It is an essential plant macronutrient which is required to build important molecules such as nucleic acids and phospholipids. Phosphorus also plays a central role during energy transfer in processes mediated by nicotinamide adenine dinucleotide phosphate (NADPH), adenosine triphosphate (ATP) and in regulation of enzymatic and metabolic reactions (Craufurd et al., 2000; Theodorou and Plaxton, 1993).

Knowledge on the effective irradiation dose on varieties developed by Institute for Agricultural Research (IAR) is currently unavailable. Obtaining high-yielding, stress-tolerant groundnut cultivars using conventional breeding methods is difficult due to limited genetic diversity in groundnuts (Sui et al., 2013). This study sought to determine the effect of radiation on growth parameters in groundnuts.

\section{MATERIALS AND METHODS}

\section{Experimental Site}

The study was carried out on an Alfisols sampled from the experimental research farm of IAR, Samaru - Zaria (lat. $11^{0} 10^{\prime} \mathrm{N}$, long. $7^{0}$ $36^{\prime} \mathrm{E}$ ). The soil of the area was described as leached tropical ferruginous, classified as Typic Haplustalf in soil taxonomy, Acrisol in the FAO system and Alfisols in the USDA system (Uyovbisere et al., 2000). The characteristic vegetation in the area is the northern Guinea savannah, having a sparse regrowth of low grass and shrubby vegetation (Kawo et al., 2006).

Soil sampling, preparation and analysis

Composite samples from surface $(0-15 \mathrm{~cm})$ and sub-surface $(15-30 \mathrm{~cm})$ of the soil were randomly collected from 5 points on the experimental site. These were thoroughly mixed, air-dried, crushed and passed through a 2-mm sieve. The less than 2-mm fraction was used for the various physical and chemical analyses conducted. This fraction was, however, further sieved through a $0.5-\mathrm{mm}$ mesh and was used for the determination of organic carbon $(\mathrm{OC})$ and total N. Another sample was also collected, from $0-15 \mathrm{~cm}$ depth, prepared and passed through a $6 \mathrm{~mm}$ mesh and was used for the pot experiment.

Three (3)-litre plastic pots, each $13.5 \mathrm{~cm}$ in length and $17.6 \mathrm{~cm}$ in diameter were used for the experiment. Three (3) $\mathrm{kg}$ of the $6 \mathrm{~mm}$ sieved soil was weighed into each pot. Each pot was perforated by making 3 holes beneath, paper was placed before the soil was put into the pots and the pot covers were placed underneath each pot in order to collect drained water, containing dissolved nutrients, which was returned into the pots appropriately.

\section{Treatments and experimental design}

The treatments consisted of two groundnut genotypes (SAMNUT 24 ${ }_{\mathrm{A}}$ and $\mathrm{B}$ and; SAMNUT 26 and $\left.{ }_{B}\right)$ and four rates $\left(0,20,40\right.$ and $60 \mathrm{~kg} \mathrm{P}_{2} \mathrm{O}_{5}$ $\mathrm{ha}^{-1}$ ) of phosphorus. The genotypes (SAMNUT 24 and SAMNUT 26) were, however, divided into two portions of which one part was irradiated (A) and the other left as was (as non-radiated, B). They were, therefore, respectively designated as irradiated and non-radiated SAMNUT $24\left(\mathrm{G}_{1 \mathrm{~A}}\right.$ and $\left.\mathrm{G}_{1 \mathrm{~B}}\right)$ and irradiated and non-radiated SAMNUT $26 \quad\left(G_{2 A}\right.$ and $\left.G_{2 B}\right)$. All treatment combinations were randomly allocated in a randomised complete block design (RCBD) and replicated three times, in a (heterogeneous) screen house of Soil Microbiology Unit of the Department of Soil Science, Ahmadu Bello University (ABU), Zaria. Seeds were exposed to thermal neutrons from an Americium-Beryllium (Am-Be) source for six days at the Centre for Energy Research and Training, Ahmadu Bello University, Zaria. The Am-Be neutron source had a thermal neutron flux of $1.3 \times 10^{4} \mathrm{n} \mathrm{cm}^{-2} \mathrm{Sec}^{-1}$. The irradiation assembly consisted of a paraffin cylinder having six symmetrical irradiation positions with the Am-Be neutron source at the centre. The source was cylindrical with a dimension of 30 $\mathrm{mm} \times 48 \mathrm{~mm}$ in diameter. The seeds were placed into a string tied-plastic bottle. This was used for placing the seeds into and from the radiation source hole (Onoja et al., 1995; Marcu et al., 2013).

\section{Data collection}

The data were collected in the three growth phases (pre-harvest, harvest and post-harvest), were obtained on weekly basis for eight weeks. The data collected (before harvest) included; plant height $(\mathrm{cm})$; measured using a $30 \mathrm{~cm}$ rule from the ground level to the apical leaf. Others were numbers of branches, leaves and flowers, as well as chlorophyll content (CC). The number observed was counted for each parameter while the CC was measured using a digital (SPAD-502Plus) chlorophyll meter (Konica Minolta Inc., 2017).

At harvest, the root, as detached from the shoot, was carefully washed with tap water immediately after harvest, and length was measured with a $30 \mathrm{~cm}$ rule. Their fresh weights were also recorded. Root nodules were earlier carefully removed with a pair of forceps and their number recorded. Thirty (30) root nodules, sampled from each plant, were used in the determination of effective nodules. Each of these nodules was sliced into two halves, using a razor blade, and active ones termed effective, were determined by their pinkish or reddish pigmentation and the number recorded. 
Those observed to be white, green, or greenish brown in colour were not active, and therefore, termed ineffective (Gwata et al., 2003). After harvest, the fresh nodules, roots and shoots were separately enveloped and oven-dried at $105{ }^{\circ} \mathrm{C}$ for 48 hours before a Mettler weighing balance was used to measure their dry weights.

Statistical analysis

All the data collected were subjected to analysis of variance (ANOVA) using generalised linear model (GLM) of the statistical analysis system (SAS) computer statistical package (SAS, 2014). Means with significant difference at $5 \%$ level of probability were separated using the Duncan's multiple range test (DMRT).

\section{RESULTS AND DISCUSSION}

\section{Physical and chemical characteristics of the} experimental soil

The physical and chemical properties of the soil, at 2 depths $(0-15 \mathrm{~cm}$ and $15-30 \mathrm{~cm})$, were determined. The result of particle size analysis showed a proportion of 54,25 , and 21 $\%$ for sand, silt and clay respectively at the depth of $0-15 \mathrm{~cm}$. At the depth of $15-30 \mathrm{~cm}$, 62,17 and $21 \%$ were respectively observed for sand, silt and clay. The textural class was observed to be a sandy clay loam (Table 1). This type of texture is regarded suitable for groundnut production (Raemaekers, 2001). The bulk density (Table 1) also indicated that the soil was good for agriculture, as soils with bulk densities greater than $1.65 \mathrm{~g} \mathrm{~cm}^{-3}$ are not agriculturally good (Vickers, 1979).

The soil reaction $(\mathrm{pH})$ was slightly acidic both in water $(5.9$ and 6.1 at $0-15 \mathrm{~cm}$ and $15-30$ $\mathrm{cm}$, respectively) and $\mathrm{CaCl}_{2}$ (4.8 and 4.5 at 0 $15 \mathrm{~cm}$ and $15-30 \mathrm{~cm}$, respectively), hence the soil was suitable for most crops, including groundnuts. Unless there is a calcium deficiency, soils with this type of acidity require no liming (Chude et al., 2004). The organic carbon content was, however, low in both depths of $0-15 \mathrm{~cm}(0.35 \%)$ and $15-30$ $\mathrm{cm}(0.42 \%)$. This type of condition encourages rapid leaching of cations and consequent low CEC values (Enwezor et al., 1990). The total $N$ and available $\mathrm{P}$ were also on the lower side (Table 1). The $\mathrm{N}$ and $\mathrm{P}$ deficiencies; and that of organic carbon/organic matter contents indicated poor nutrient reserve of the soil.

Effects of genotype and $P$ rate on plant height, numbers of branches, leaves and flowers in the groundnut genotypes

There was a significant $(P<0.05)$ difference between the genotypes in terms of plant height and numbers of branches, leaves and flowers (Table 2). Irradiation significantly $(P \leq 0.05)$ affected most of the growth parameters observed in the genotypes (Table 2). There was also a significant $(P<0.0001)$ effect of the interaction of genotype and $P$ rate in terms of plant height (Tables 2 and 3); and numbers of branches (Tables 2 and 4 ) and leaves (Tables 2 and 5$)$, but not $(P>0.05)$ the number of flowers (Table 2). Tallest plants were observed in the irradiated SAMNUT $26\left(\mathrm{G}_{2 \mathrm{~A}}\right)$ at all the $\mathrm{P}$ rates. This genotype was, however, statistically similar with the non-radiated SAMNUT $26\left(\mathrm{G}_{2 \mathrm{~B}}\right)$ at $0 \mathrm{~kg} \mathrm{P}_{2} \mathrm{O}_{5} \mathrm{ha}^{-1}$ rate (Table 3). This indicated neither a need for irradiation nor $\mathrm{P}$ application to achieve a good plant height in SAMNUT 26. Irradiation and an economical application of $\mathrm{P}$ at $20 \mathrm{~kg} \mathrm{P} \mathrm{P}_{2} \mathrm{ha}^{-1}$ is, however, needed in SAMNUT 24 in order to produce plants with a good height (Table 3 ). The non-radiated $G_{1 B}$ produced the least plant height (Tables 2 and $3)$. Highest mean plant height was observed by Rao (1988) and Khan et al. (1989) due to gamma radiation-induced variability. Salve and Gunjal (2011) reported statistically similar plant height records under an application of 50 and $75 \mathrm{~kg} \mathrm{P}_{2} \mathrm{O}_{5}$ ha $^{-1}$ in groundnuts, compared to the application of $25 \mathrm{~kg} \mathrm{P}_{2} \mathrm{O}_{5}$, ha ${ }^{-1}$.

Highest number of branches was recorded in the irradiated genotypes and $\mathrm{P}$ application of 20,40 and $60 \mathrm{~kg} \mathrm{P}_{2} \mathrm{O}_{5} \mathrm{ha}^{-1}$, which were at par, except in case of $\mathrm{G}_{1 \mathrm{~A}}$ at $40 \mathrm{~kg} \mathrm{P}_{2} \mathrm{O}_{5} \mathrm{ha}^{-1}$ (Table 4). This suggested for a need of irradiation and a $\mathrm{P}$ application of $20 \mathrm{~kg} \mathrm{P}_{2} \mathrm{O}_{5} \mathrm{ha}^{-1}$ for a good number of branches in the two (SAMNUT 24 and SAMNUT 26) genotypes. Shiyam (2010), in a study, reported a non-significant difference between $\mathrm{P}$ rates on plant height and numbers of flowers and branches. However, Gobarah et al. (2006) reported an increase in vegetative growth due to increase in $\mathrm{P}$ rate of application. Application of $P$ fertiliser also increased number of branches at growth stage in a study by Alam et al. (2009). Adequate $P$ rates were observed to promote root growth, stimulate branching and hasten maturity (USDA, 2014). The two irradiated $\left(\mathrm{G}_{1 \mathrm{~A}}\right.$ and $\left.\mathrm{G}_{2 \mathrm{~A}}\right)$ genotypes each produced statistically similar and more leaves, also at $20 \mathrm{~kg} \mathrm{P}_{2} \mathrm{O}_{5} \mathrm{ha}^{-1}$ rate of application. These were, however, at par with $\mathrm{G}_{1 \mathrm{~A}}, \mathrm{G}_{2 \mathrm{~A}}$ and $\mathrm{B}$, at $60 \mathrm{~kg}_{2} \mathrm{O}_{5} \mathrm{ha}^{-1}$ and $\mathrm{G}_{2 \mathrm{~A}}$ at 40 $\mathrm{kg} \mathrm{P}_{2} \mathrm{O}_{5}$ ha $^{-1}$ (Table 4), thus further reaffirming the $20 \mathrm{~kg} \mathrm{P}_{2} \mathrm{O}_{5} \mathrm{ha}^{-1}$ as a more economical rate of application also for number of leaves in the groundnuts.

Effects of genotype and $\mathrm{P}$ rate on chlorophyll content, nodule number and effective nodulation of the groundnut genotypes

There was no significant $(P>0.05)$ difference in the effect of genotype on chlorophyll content (CC), nodule number and effective nodulation. However, the $P$ rates of application differ significantly $(P<0.0001)$ in terms of all the parameters (Table 6). 
All the $\mathrm{P}$ rates were statistically at par with respect to CC of the genotypes, except $0 \mathrm{~kg}$ $\mathrm{P}_{2} \mathrm{O}_{5} \mathrm{ha}^{-1}$, which had the lowest CC record. The two nodule parameters were statistically at their best at 40 and $60 \mathrm{~kg} \mathrm{P}_{2} \mathrm{O}_{5} \mathrm{ha}^{-1}$ rates of application, compared to the also statistically similar but lowest 0 and $20 \mathrm{~kg} \mathrm{P}_{2} \mathrm{O}_{5}$ ha $^{-1}$ (Table 6 ). Good CC, nodule number and effective nodulation can, therefore, be more economically achieved through the application of 20 and $40 \mathrm{~kg} \mathrm{P}_{2} \mathrm{O}_{5} \mathrm{ha}^{-1}$, respectively (Table $6)$.

The effect of interaction on CC and effective nodulation of the genotypes was not significant $(P>0.05)$, it was, however, significant $(P<0.0001)$ for the nodule number observed (Table 6 and Figure 1). Irradiated $\left(\mathrm{G}_{1 \mathrm{~A}}\right.$ and $\left.\mathrm{G}_{2 \mathrm{~A}}\right)$ genotypes recorded the highest number of nodules at 60 and $40 \mathrm{~kg} \mathrm{P}_{2} \mathrm{O}_{5} \mathrm{ha}^{-1}$ respectively, whereas $G_{1 B}$ and $G_{2 B}$ were statistically similar at $60 \mathrm{~kg} \mathrm{P}_{2} \mathrm{O}_{5} \mathrm{ha}^{-1}$ and together followed those (Figure 1). Irradiated $\mathrm{G}_{2 \mathrm{~A}}$, at $40 \mathrm{~kg} \mathrm{P}_{2} \mathrm{O}_{5} \mathrm{ha}^{-1}$ rate of application, can be good for an enhanced nodule formation compared to the other genotypes and $\mathrm{P}$ rates. Hence, it had a better chance of possible high yield due to its good $\mathrm{N}_{2}$ fixation potential, depending on the effectiveness of the nodules to be formed. Increase in shoot dry weight, nodule number, nodule mass, nodule size and nodulation index were observed due to availability of $P$ in a study by Kuang et al. (2005). Mapfumo et al. (2005) reported that $P$ availability has been widely observed to have a significant effect on nodulation, $\mathrm{N}$ accumulation and biomass production. The 60 and $40 \mathrm{~kg} \mathrm{P}_{2} \mathrm{O}_{5} \mathrm{ha}^{-1}$ had the highest nodules numbers and effective nodules, because $P$ is required for the normal functioning of nitrogen fixing bacteria (the microsymbiont) and thus has a favourable effect on the nodule parameters (Mapfumo et al., 2005), which are a part of the fixation indices. Thus, the lower nodulation, which may eventually lead to lower $\mathrm{N}_{2}$-fixation, in genotypes that received 0 and $20 \mathrm{~kg} \mathrm{P}_{2} \mathrm{O}_{5} \mathrm{ha}^{-1}$, was due to the limited supply of available $P$, as its deficiency decreases nodulation and $\mathrm{N}_{2}$ fixation (Tang et al., 2001).

Table 1: Characterisation of the experimental soil

\begin{tabular}{llll}
\hline Parameter & Unit & \multicolumn{2}{c}{ Depth (cm) } \\
\cline { 3 - 4 } & & $\mathbf{0 - 1 5}$ & $\mathbf{1 5 - 3 0}$ \\
\hline Particle size distribution & $\%$ & 54.00 & 62.00 \\
Sand & $\%$ & 25.00 & 17.00 \\
Silt & $\%$ & 21.00 & 21.00 \\
Clay & - & Sandy clay loam & Sandy clay loam \\
Textural class & $\mathrm{g} \mathrm{cm}^{-3}$ & 1.34 & 1.34 \\
Bulk density & - & 5.90 & 6.10 \\
pH (water) & - & 4.80 & 4.50 \\
pH (CaCl $)$ & $\mathrm{g} \mathrm{kg}^{-1}$ & 0.35 & 0.42 \\
Organic C & $\mathrm{g} \mathrm{kg}^{-1}$ & 6.80 & 7.20 \\
Organic matter* & $\mathrm{g} \mathrm{kg}^{-1}$ & 0.65 & 0.45 \\
Total N & $\mathrm{mg} \mathrm{kg}^{-1}$ & 3.30 & 4.20 \\
Available P & $\mathrm{Cmol}^{*}+\mathrm{kg}^{-1}$ & & \\
Exchangeable Bases & & 0.50 & 0.19 \\
K & & 0.53 & 0.15 \\
Na & & 2.60 & 2.40 \\
Ca & & 0.77 & 0.72 \\
Mg & & & 10.20 \\
CEC & &
\end{tabular}

${ }^{*}$ OC $\left(\mathrm{g} \mathrm{kg}^{-1}\right) \times 1.724$ (Juo, 1979) 
Table 2: Effect of genotype and $\mathrm{P}$ rate on plant height and numbers of branches, leaves and flowers

\begin{tabular}{lllll}
\hline Treatments & $\begin{array}{l}\text { Plant height }(\mathrm{cm} \\
\left.\text { plant }^{-1}\right)\end{array}$ & $\begin{array}{l}\text { Number of } \\
\text { branches } \\
\text { plant }\end{array}$ & $\begin{array}{l}\text { Number of } \\
\text { leaves plant }\end{array}$ & $\begin{array}{l}\text { Number of } \\
\text { flowers plant }^{-1}\end{array}$ \\
\hline Genotype $(\mathrm{G})$ & & & & \\
SAMNUT 24-A $\left(\mathrm{G}_{1 \mathrm{~A}}\right)$ & $15.1^{\mathrm{b}}$ & $10.7^{\mathrm{a}}$ & $46.2^{\mathrm{a}}$ & $8.2^{\mathrm{a}}$ \\
SAMNUT 24-B $\left(\mathrm{G}_{1 \mathrm{~B}}\right)$ & $13.4^{\mathrm{c}}$ & $8.1^{\mathrm{b}}$ & $35.3^{\mathrm{c}}$ & $5.5^{\mathrm{b}}$ \\
SAMNUT 26-A $\left(\mathrm{G}_{2 \mathrm{~A}}\right)$ & $16.5^{\mathrm{a}}$ & $10.5^{\mathrm{a}}$ & $46.2^{\mathrm{a}}$ & $5.2^{\mathrm{b}}$ \\
SAMNUT 26-B $\left(\mathrm{G}_{2 \mathrm{~B}}\right)$ & $13.7^{\mathrm{c}}$ & $9.9^{\mathrm{a}}$ & $41.3^{\mathrm{b}}$ & $4.1^{\mathrm{b}}$ \\
$\mathrm{SE} \pm$ & 0.35 & 0.40 & 1.57 & 0.51 \\
$\mathrm{P}$ rate $\left(\mathrm{P}, \mathrm{kg}_{2} \mathrm{O}_{5} \mathrm{ha}^{-1}\right)$ & & & & \\
0 & $14.2^{\mathrm{b}}$ & $7.9^{\mathrm{c}}$ & $34.9^{\mathrm{c}}$ & $5.3^{\mathrm{b}}$ \\
20 & $14.6^{\mathrm{ab}}$ & $9.7^{\mathrm{b}}$ & $41.4^{\mathrm{b}}$ & $7.0^{\mathrm{a}}$ \\
40 & $14.5^{\mathrm{ab}}$ & $10.0^{\mathrm{b}}$ & $42.6^{\mathrm{b}}$ & $3.4^{\mathrm{c}}$ \\
60 & $15.4^{\mathrm{a}}$ & $11.5^{\mathrm{a}}$ & $49.9^{\mathrm{a}}$ & $7.4^{\mathrm{a}}$ \\
$\mathrm{SE} \pm$ & 0.32 & 0.40 & 1.57 & 0.51 \\
Interactions & $* *$ & $* *$ & & \\
$\mathrm{G} \times \mathrm{P}$ & & $* *$ & $\mathrm{NS}$ \\
\hline
\end{tabular}

${ }^{* *}=$ significant at $1 \%$ level probability, NS $=$ Not significant at $5 \%$ level of probability, means with the same letter(s) within a column are not significantly different according to DMRT.

Table 3 Effect of genotype and $P$ interaction on plant height of the genotypes

\begin{tabular}{lcccc}
\hline \multirow{2}{*}{ Genotype } & \multicolumn{4}{c}{ Phosphorus rate $\left(\mathrm{kg} \mathrm{P}_{2} \mathrm{O}_{5} \mathbf{h a}^{-1}\right)$} \\
\cline { 2 - 5 } & 0 & 20 & 40 & 60 \\
\hline SAMNUT 24-A & $13.82^{\mathrm{b}-\mathrm{f}}$ & $15.85^{\mathrm{a}-\mathrm{d}}$ & $16.72^{\mathrm{ab}}$ & $13.93^{\mathrm{b}-\mathrm{f}}$ \\
SAMNUT 24-B & $13.62^{\mathrm{c}-\mathrm{f}}$ & $12.22^{\mathrm{ef}}$ & $13.95^{\mathrm{b}-\mathrm{f}}$ & $13.77^{\mathrm{b}-\mathrm{f}}$ \\
SAMNUT 26-A & $14.89^{\mathrm{a}-\mathrm{e}}$ & $17.37^{\mathrm{a}}$ & $16.42^{\mathrm{a}-\mathrm{c}}$ & $17.26^{\mathrm{a}}$ \\
SAMNUT 26-B & $14.65^{\mathrm{a}-\mathrm{e}}$ & $12.81^{\mathrm{d}-\mathrm{f}}$ & $10.94^{f}$ & $16.50^{\mathrm{a}-\mathrm{c}}$ \\
\hline
\end{tabular}

$\mathrm{SEM} \pm=0.700$

Table 4 Effect of genotype and $P$ interaction on number of branches of the genotypes

\begin{tabular}{lcccc}
\hline \multirow{2}{*}{ Genotype } & \multicolumn{4}{c}{ Phosphorus rate $\left(\mathbf{k g ~ P}_{2} \mathrm{O}_{5} \mathbf{h a}^{-1}\right)$} \\
\cline { 2 - 5 } & $\mathbf{0}$ & $\mathbf{2 0}$ & $\mathbf{4 0}$ & $\mathbf{6 0}$ \\
\hline SAMNUT 24-A & $9.71^{\mathrm{b}-\mathrm{e}}$ & $11.58^{\mathrm{ab}}$ & $9.83^{\mathrm{b}-\mathrm{d}}$ & $11.71^{\mathrm{ab}}$ \\
SAMNUT 24-B & $6.25^{\mathrm{e}}$ & $9.42^{\mathrm{b}-\mathrm{e}}$ & $7.92^{\mathrm{c}-\mathrm{e}}$ & $8.79^{\mathrm{b}-\mathrm{e}}$ \\
SAMNUT 26-A & $7.88^{\mathrm{ce}}$ & $11.50^{\mathrm{ab}}$ & $10.75^{\mathrm{a}-\mathrm{c}}$ & $11.75^{\mathrm{ab}}$ \\
SAMNUT 26-B & $7.96^{\mathrm{c}-\mathrm{e}}$ & $6.38^{\mathrm{de}}$ & $11.46^{\mathrm{ab}}$ & $13.88^{\mathrm{a}}$ \\
\hline
\end{tabular}

$\mathrm{SEM} \pm=0.800$

Table 5 Effect of genotype and $P$ interaction on number of leaves of the genotypes

\begin{tabular}{lcccc}
\hline \multirow{2}{*}{ Genotype } & \multicolumn{4}{c}{ Phosphorus rate $\left(\mathrm{kg} \mathrm{P}_{2} \mathrm{O}_{5} \mathrm{ha}^{-1}\right)$} \\
\cline { 2 - 5 } & 0 & 20 & 40 & 60 \\
\hline SAMNUT 24-A & $42.58^{\mathrm{b}-\mathrm{d}}$ & $49.75^{\mathrm{ab}}$ & $43.25^{\mathrm{b}-\mathrm{d}}$ & $48.58^{\mathrm{a}-\mathrm{c}}$ \\
SAMNUT 24-B & $26.75^{\mathrm{e}}$ & $39.83^{\mathrm{b}-\mathrm{e}}$ & $34.50^{\mathrm{d}-\mathrm{f}}$ & $39.96^{\mathrm{b}-\mathrm{e}}$ \\
SAMNUT 26-A & $35.75^{\mathrm{c}-\mathrm{f}}$ & $50.33^{\mathrm{ab}}$ & $46.96^{\mathrm{a}-\mathrm{d}}$ & $51.63^{\mathrm{ab}}$ \\
SAMNUT 26-B & $34.42^{\mathrm{d}-\mathrm{f}}$ & $25.71^{\dagger}$ & $45.50^{\mathrm{b}-\mathrm{d}}$ & $59.42^{\mathrm{a}}$ \\
\hline
\end{tabular}

SEM $=3.140$ 


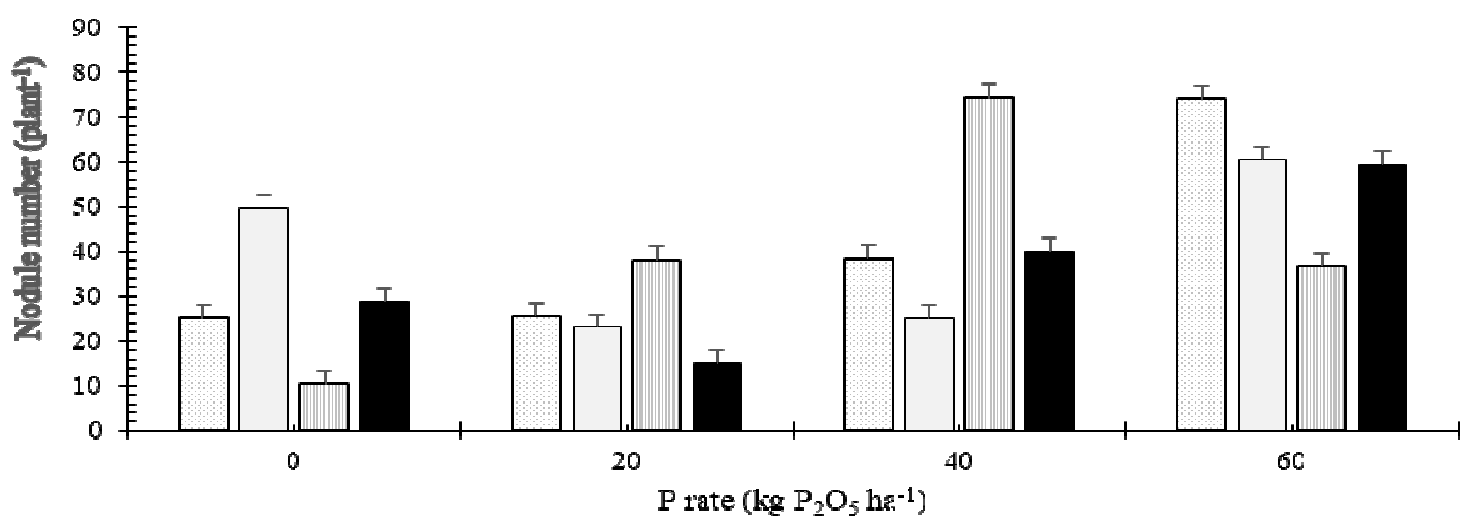

口Iradiated SAMNUT 24 口Non-radiated SAMNUT 24 口Iradiated SAMNUT 26 DNon-radiated SAMNUT 26

Figure 1 Effect of genotype and $P$ rate interaction on nodule number of the groundnuts

Table 6: Effects of genotype and $\mathrm{P}$ rate on chlorophyll content, nodule number and effective nodulation of the groundnut genotypes

\begin{tabular}{|c|c|c|c|}
\hline Treatments & $\begin{array}{l}\text { Chlorophyll content } \\
\text { (SCMR) }\end{array}$ & Nodule number plant- ${ }^{-}$ & $\begin{array}{l}\text { Effective nodules } \\
\text { plant- }^{1}\end{array}$ \\
\hline \multicolumn{4}{|l|}{ Genotype (G) } \\
\hline SAMNUT $24-A\left(G_{1 A}\right)$ & 47.24 & 42.50 & 4.58 \\
\hline SAMNUT 24-B $\left(\mathrm{G}_{1 \mathrm{~B}}\right)$ & 49.38 & 42.00 & 5.00 \\
\hline SAMNUT 26-A $\left(\mathrm{G}_{2 \mathrm{~A}}\right)$ & 48.83 & 40.00 & 5.82 \\
\hline SAMNUT 26-B $\left(\mathrm{G}_{2 \mathrm{~B}}\right)$ & 48.50 & 37.96 & 4.58 \\
\hline $\mathrm{SE} \pm$ & 1.664 & 3.241 & 0.497 \\
\hline \multicolumn{4}{|l|}{$P$ rate $(P)$} \\
\hline 0 & $43.81^{b}$ & $28.41^{\mathrm{b}}$ & $3.83^{\mathrm{b}}$ \\
\hline 20 & $49.69^{\mathrm{a}}$ & $26.82^{b}$ & $3.91^{\mathrm{b}}$ \\
\hline 40 & $49.43^{\mathrm{a}}$ & $48.54^{\mathrm{a}}$ & $6.33^{\mathrm{a}}$ \\
\hline 60 & $51.02^{\mathrm{a}}$ & $57.58^{\mathrm{a}}$ & $5.75^{\mathrm{a}}$ \\
\hline $\mathrm{SE} \pm$ & 1.664 & 3.241 & 0.497 \\
\hline \multicolumn{4}{|l|}{ Interaction } \\
\hline$G \times P$ & NS & $* *$ & NS \\
\hline
\end{tabular}

SCMR = SPAD Chlorophyll Meter Reading (Sonsgri et al., 2009), NS = Not significant at $5 \%$ level of probability, ${ }^{* *}=$ significant at $1 \%$ level probability, means with the same letter(s) within a column are not significantly different according to DMRT.

\section{CONCLUSION}

The study showed that the irradiation had significant impact on the genotypes. It was observed that gamma irradiation played an important role in increasing groundnut performance such as in plant height and numbers of branches, leaves and flowers, as well as chlorophyll content. Non-radiated SAMNUT 26, and without $P$ application, was observed to be best for plant height. Irradiation and $\mathrm{P}$ application at $20 \mathrm{~kg} \mathrm{P}_{2} \mathrm{O}_{5} \mathrm{ha}^{-1}$ is recommended for an economically optimum chlorophyll content; and numbers of branches and leaves in the groundnut genotypes. The two nodule parameters were best at $40 \mathrm{~kg} \mathrm{P}_{2} \mathrm{O}_{5}$ $\mathrm{ha}^{-1}$. More research should be conducted on effects of different irradiation sources and exposure duration on various groundnut performances.

\section{Acknowledgements}

The authors wish to recognise the support of the Department of Soil Science, Ahmadu Bello University (ABU), Zaria, for providing the enabling environment of conducting the experiment. Contribution of Mal. Ado Garba, Centre for Energy Research and Training, ABU, Zaria, in irradiating the seeds is also well acknowledged. 


\section{REFERENCES}

Alam M.M., Ali M.H., Ruhulamin A.K.M., Hassanuzzaman M. (2009). Yield attributes, yield and harvest index of three irrigated rice varieties under different levels of phosphorus. Advance in Biological Research, 3 (34): 132-139 (a).

Aparna, M., Chaturvedi, A., Sreedhar, M., Kumar, D.P., Venu-Babu, P. and Singhal, R.K. (2012). Impact of gamma rays on the seed germination and seedling parameters of groundnut (Arachis hypogaea L.). Asian J. Exp. Biol. Sci., 4 (1): 61- 68.

Arcand, M. and Schneider, K. (2006). Plant and microbial-based mechanisms to improve the agronomic effectiveness of phosphate rock: a review. Annals of the Brazilian Academy of Sciences. 78: 791807.

http://harvestchoice.org/commodities/ groundnut

Chude, C.O., Malgwi, W.B., Amapu, I.Y. and Ano, O.A. (2004). Manual on soil fertility assessment. Federal Fertilizer Department (FFD), in collaboration with National Special Programme for Food Security, AbujaNigeria.

Craufurd P.Q., Wheeler T.R., Ellis R.H., Summerfield R.J. and Prasad P.V.V. (2000). Escape and tolerance to high temperature at flowering in groundnut (Arachis hypogaea L.). Journal of Agricultural Science, Cambridge 135, 371-378.

Enwezor, W.O., Udo, E.J. Ayotade, K.A., Adepelu, J.A. and Chude, V.O. (1990). Literature review on soil fertility investigation in Nigeria (In five volumes): Federal Ministry of Agriculture and Natural Resources: Lagos, Nigeria.

Fairhust, T.R., Lefroy, R., Mutert, E. and Batijes, N. (1999). The importance, distribution and causes of phosphorus deficiency as a constraint to crop production in the tropics. Agroforestry Forum, 9(4): 2-8.

FAOSTAT (2011). Food and agricultural organisation production year book. Vol. 40. Food and Agriculture Organisation of the United Nations, Rome, p.116.

Gobarah, M.E., Mohamed, M.H. and Tawfik, M.M. (2006). Effect of phosphorus fertilizer and foliar spraying with zinc on growth, yield and quality of groundnut under reclaimed sandy soils. Journal of Applied Science

Research, 2(8): 491- 496.

Gwata, E.T., Wofford, D.S., Boote, K.J. and Mushoriwa, H. (2003). Determination of effective nodulation in early juvenile soybean plants for genetic and biotechnology studies. African Journal of Biotechnology, 2 (11): 417-420. ISSN 1684-5315.

Isleib, T.G., Wynne, J.C., Nigam, S.N. (1994). Groundnut breeding. In: Smartt, J. (Ed.). The Groundnut Crop: A scientific basis for improvement. (London: Chapman \& Hall), pp. 552 -623.

Juo, A.S.R. (1979). (Ed). Selected methods for soil and plant analysis. Manual series No. 1 IITA.

Kawo, A.H., Aliyu, B.S., Mukhtar, M.D. and Bashir, H. (2006). Ecology at a Glance. Benchmark Publishers Limited, Kano.

Khan, A., Hayat, K., Hassan, S., Sadiq, M. and Hashim, M. (1989). Gamma radiation induced variation in some genetic parameters in sorghum cultivars in $M 2$ generation. Sarhad Journal of Agriculture, 5 (2): 199-203.

Konica Minolta Inc. (2017). SPAD-502Plus $®$ : A lightweight handheld meter for measuring the chlorophyll content of leaves without causing damage to plants. @ 2009 - 2017 KONICA MINOLTA INC., $\quad$ Japan. http://konicaminolta.com/instruments /network.

Kuang, R.B., Liao, H., Yan, X.L. and Dong, Y.S. (2005). Phosphorus and nitrogen interaction in field grown soybeans as related to genetic attribute of the root morphological and nodular traits. Journal of Integrative Plant Biology. 47:549-559.

Mapfumo, P., Mtambanengwe, F.F., Giller, K.E., and Mpepereki, S. (2005). Tapping indigenous herbaceous legumes for soil fertility management by resource-poor farmers in Zimbabwe. Agriculture Ecosystem and environment, 109: 221233.

Marcu, D., Damian, G., Cosma, C. and Cristea, V. (2013). Gamma radiation effects on seed germination, growth and pigment content, and ESR study of induced free radicals in maize (Zea mays). Journal of Biological Physics, 39: 625-634. DOI 10.1007/s10867-013-9322-z

Micke, A. (1997). Mutation breeding of grain legumes. $15^{\text {th }}$ IAEA/FAO, Inter-regional training course in advances in technologies of induced mutations in crops, $20^{\text {th }}$ May - 27 $7^{\text {th }}$ June 1997. 
Onoja, A., Umar, I.M., Funtua, I.I., Dim, L.A. and Elegba, S.B. (1995). Design, construction and characterization of a low neutron flux irradiation facility. Nigerian Journal of physics, 7: 76-80.

Raemaekers, R.H. (ed.). (2001). Crop production in tropical Africa. Directorate General for International Co-operation (DGIC), Brussels, Belgium.

Ramani, G.M. and Jadon, B.S. (1991). Induced variability in groundnut in $M 2$ Generation. Gujarat Agricultural University Research Journal, 16(2): 2326.

Rao, S.K. (1988). Gamma ray induced morphological and physiological variations in Cicer arietinum L. Indian Journal of Botany, 11 (1): 29-32.

Salve, Y.V. and Gunjal, B.S. (2011). Effect of different levels of phosphorus and potassium on summer groundnut (Arachis hypogaea L.). International Journal of Agricultural Science, 7 (2): 352-355.

SAS (2014). Statistical Analysis System Institute. SAS 9.4. SAS Institute, Inc., Cary, NC.

Shiyam, J.O. (2010). Growth and yield response of groundnut (Arachis hypogaea L.) to plant densities and phosphorus on an Ultisols in South-eastern Nigeria. Libyan Agricultural Research Centre Journal International, 1 (4): 211-214.

Songsri, P., Jogloy, S., Holbrook, C.C., Kesmala, T., Vorasoot, N., Akkasaeng, C. and Patanothai, A. (2009). Association of root, specific leaf area and SPAD chlorophyll meter reading to water use efficiency of peanut under different available soil water.
Agricultural Water Management, 96: 790-798.

Sui, J.M., Li, R. and Fan, Q.C. (2013). Isolation and characterization of a stress responsive small GTP-binding protein AhRabG3b in peanut (Arachis hypogaea L.). Euphytica, 189:161- 72.

Tang, S., Qiu, J., Nikulina, E. and Filbin, M.T. (2001). Soluble myelin-associated glycoprotein released from damaged white matter inhibits axonal regeneration. Molecular and Cellular Neuroscience, 18 (3): 259-69.

Theodorou, M.E. and Plaxton, W.C. (1993). Metabolic adaptations of plant respiration to nutritional phosphate deprivation. Plant Physiology, 101: 339-344.

Tshilenge-Lukanda, L., Mbuyi, A.K., Nkongolo, K.K.C. and Kizungu, R.V. (2013). Effect of gamma irradiation on morphoagronomic characteristics of groundnut (Arachis hypogaea L.). American Journal of Plant Science, 4: 2186-2192.

USDA (2014). United States Department ofAgriculture, Natural Resources Conservation Service. Soil Quality KitGuide for Educators.

Uyovbisere, E.O., Chude, V.O. and Bationo, A. (2000). Promising nutrient ratios in fertilizer formulations for optimal performance of maize in the Nigerian savanna: The need for a review of current recommendation. Nigerian Journal of Soil Research, 1: 29-34.

Vickers, B. (1979). Laboratory work in civil engineering soil mechanics. Granada Publishers, New York. 